\title{
NEUROPROTECTIVE ANTIOXIDANT EFFECT OF PORTULACA QUADRIFIDA LINN. LEAVES EXTRACT ON IMMOBILIZATION STRESS-INDUCED CHANGES IN RAT'S BRAIN
}

\author{
MOAYAD JAMAL SHAHWAN*, SABRINA AIT GACEM \\ Department of Clinical Sciences, College of Pharmacy and Health Sciences, Ajman University, Ajman, United Arab Emirates. \\ Email: moyad76@hotmail.com
}

Received: 09 May 2018, Revised and Accepted: 25 June 2018

\section{ABSTRACT}

Objective: The current study was established to illustrate the effect of this plant's active constituents on stress-induced diseases that include oxidation damage to cellular components, especially the brain.

Methods: Immobilization stress method is induced and initiated by putting separated animals in specially prepared mesh cages on a wooden plank. The animals were exposed to $6 \mathrm{~h}$ of stress. Wistar male rats were selected weighing (180-200 g). A total of 54 rats were selected and separated into nine groups and only six experimental rats were kept in each group.

Results: The post-stress oral treatment of extract $(100 \mathrm{mg} / \mathrm{kg}$ body weight) was more efficient in restricting stress-induced decline of superoxide dismutase $(\mathrm{p}<0.05)$, glutathione $(\mathrm{GSH})$-S-transferase $(\mathrm{p}<0.02)$, catalase $(\mathrm{p}<0.05)$, and GSH $(\mathrm{p}<0.05)$ and an enhanced level of thiobarbituric acid reactive substance $(\mathrm{p}<0.01)$ compared to stress alone or pre-stress extract treatments.

Conclusion: The extract showed a significant resistance toward the oxidative metabolism triggered by restraint stress, though the post-extract treatment (curative) was observed to be more effective in restoring the altered oxidative metabolism compared with pre-extract treatment (prophylactic).

Keywords: Antioxidant, Immobilization, Neurodegenerative diseases, Portulaca quadrifida, Stress.

(C) 2018 The Authors. Published by Innovare Academic Sciences Pvt Ltd. This is an open access article under the CC BY license (http://creativecommons. org/licenses/by/4. 0/) DOI: http://dx.doi.org/10.22159/ajpcr.2018.v11i10..27209

\section{INTRODUCTION}

Most disorders are principally related to oxidative stress because of availability of reactive oxygen species. Widely recognized sorts of free radicals include, for example, superoxide anion $\left(\mathrm{O}_{2}^{-2}\right)$ and hydroxyl radicals $(\mathrm{OH})$ and also some non-free radical species, for example, hydrogen peroxide $\left(\mathrm{H}_{2} \mathrm{O}_{2}\right)$ which are engaged with the pathophysiology and pathogenesis of diseases such as viral infections and inflammation [1]. Some of them have a positive impact in vivo, as they are used for energy generation, phagocytosis, direction of cell development, and growth as well as signaling between cells [2]. The free radicals are extremely harmful and cause damage when they attack the unsaturated fatty acids and cause oxidation that results in peroxidation of membrane lipid and DNA mutation which leads to cancer [3]. The scavenger of these free radical species might be conceivably counteracting and preventing interventions of the diseases caused by free radical damage [4]. There has been expanding interest for discovering natural antioxidants from plant sources to replace non-natural synthetic ones [5]. Natural antioxidants that are broadly present in plants can end the oxidative response intervened by free radicals and will have advantageous roles in protecting the body from these diseases [6]. Polyphenolic compounds are exceptionally efficient in counteracting the oxidative stress and useful to the human body [7]. These intense heterogeneous antioxidants interfere with the oxidative or antioxidative capability of the cell [8]. Traditional drug practitioners believe that plant components contain dynamic constituents that are important in enhancing the well-being of their patients and can be an alternative treatment [9]. Food antioxidants are very important due to their protective and defensive effect against oxidative stress, which involved in causing conditions such as anemia, diabetes, cardiovascular disease, and cancer. Portulaca quadrifida L. is a little, scattered, and succulent herb found all through the Mediterranean countries, and it belongs to the Portulacaceae family. It is utilized as a vegetable and also efficient in asthma, coughing, urinary discharge, infections, and ulcers as well as abdominal disorders, allergic dermatitis, and hemorrhoids [10]. This plant demonstrated antifungal activity against Candida albicans and Aspergillus fumigates [11]. Despite the fact that there are different secondary metabolites in various extracts of the plant that was uncovered and revealed in some studies [12]. The current examination is to identify the antioxidant cancer prevention effect of ethanol and polyphenolic extracts from $P$. quadrifida Linn. In the current study, oxidative stress is induced by limited restricted mobility and was estimated in terms of free radicals enzyme activities as catalase (CAT), superoxide dismutase (SOD), thiobarbituric acid reactive substances (TBARS), and glutathione (GSH)-S-transferase (GST). Antioxidant activity of aqueous extract of $P$. quadrifida Linn. leaves and their active ingredients were additionally examined beside the pre- and post-immobilization stress triggered oxidant or prooxidant status. The results are probably going to add to the understanding of $P$. quadrifida Linn. Extract effect in preventing or reducing stress-induced conditions that include oxidation damage to cellular damage, especially the brain. The objective of our study is to illustrate the impact of P. quadrifida extract on prooxidant changes induced by immobilization stress and identify the effect of active constituents of $P$. quadrifida on stress.

\section{METHODS}

Aqueous extract preparation from $P$. quadrifida leaves

Fresh leaves were collected locally and dried at room temperature. Aqueous powder was prepared and set up by reflux with deionized water at $80{ }^{\circ} \mathrm{C}$. An amount of $100 \mathrm{mg} / \mathrm{ml}$ was set for use in oral administration.

\section{Alkaloid and flavonoid fractions preparation}

Dried leaves were powdered (500 g) and soaked in $1 \mathrm{l}$ of methanol for 1 week under reduced pressure; it was dissolved in $1 \mathrm{l}$ of ethyl acetate extracted with a $(5 \%)$ aqueous hydrochloric acid $(3 \times / 100 \mathrm{ml})$. The later 
steps were done several times until a weak reaction with Dragendorff's reagent was shown. After extraction with diethyl ether $(500 \mathrm{ml} \times 3)$, $25 \% \mathrm{NH}_{4} \mathrm{OH}$ was used to neutralize the acidic solution to a $\mathrm{pH}$ of 9-10 and then treated with chloroform. To obtain the alkaloid extract for the intragastric administration to rats, the samples were dried over sodium sulfate after being washed twice with water. To get rid of all phenolic components, the concentrated $\mathrm{HCl}$ was added to neutralize remaining part of the extract and treated several times with ethyl acetate until negative reaction observed for ferric chloride (ethyl acetate extract) with soluble extract was administered intragastrically to rats.

\section{Animal model}

Wistar male rats were selected weighing (180-200 g). The animals were in cages and divided and partitioned into groups; the Purina diet was supplied and provided with tap water ad libitum. Before starting, the animals were kept at room temperature $24 \pm 2{ }^{\circ} \mathrm{C}$ and light/dark cycles $12 \mathrm{~h}$.

\section{Experimental groups}

To identify the ideal therapeutic dose which can modulate the free radical metabolism, a preliminary dose-dependent study $(\mathrm{n}=3)$ was done (results not shown). It was seen that the extract at $100 \mathrm{mg} / \mathrm{kg}$ dose for $2 \mathrm{~h}$ had the most efficient preventive activity on oxidative stress changes in the brain.

A total of 54 rats were chosen and separated into nine groups (one control group, one stress group, one group for crude extract, and six groups for active constituents). Only six experimental rats were kept in each group according to the latest guidelines for animal reduction in experiments.

The groups were divided as follows:

- First group (control group): Received normal saline orally

- Second group (stressed): Was subjected to immobilization stress

- Third group (crude extract): Received the aqueous extract orally $(100 \mathrm{mg} / \mathrm{kg})$

- Fourth group: Received alkaloid extract of the same dose

- Fifth group: Received alkaloid extracts of the same dose $1 \mathrm{~h}$ before (pre-stress treatment) the $6 \mathrm{~h}$ session of stress

- Sixth group: Received alkaloid extracts of the same dose $1 \mathrm{~h}$ after (post-stress treatment) the $6 \mathrm{~h}$ session of stress

- Seventh group: Received flavonoid extract of the dose $(100 \mathrm{mg} / \mathrm{kg}$ body weight)

- Eighth group: Received flavonoid extracts of the same dose $1 \mathrm{~h}$ before (pre-stress treatment) the $6 \mathrm{~h}$ session of stress

- Ninth group: Received flavonoids extracts of the same dose $1 \mathrm{~h}$ after (post-stress treatment) the $6 \mathrm{~h}$ session of stress.

\section{Immobilization stress method}

Immobilization stress induced and initiated by putting separated animals in specially prepared mesh cages on a wooden plank. The animals were deprived of water and food during exposure to stress [13]. The animals were exposed to $6 \mathrm{~h}$ of stress. Control group of rats treated at the same time as stressed and placed in separated cages in a timely manner.

\section{Experimental protocol}

After the termination of experiment, the rats were sacrificed by injecting sodium pentobarbital $(50 \mathrm{mg} / \mathrm{kg})$ and exsanguinated. Blood was collected and centrifuged at $5000 \mathrm{rpm}$ for $15 \mathrm{~min}$; plasma was separated and quick-frozen at $-40^{\circ} \mathrm{C}$ until assay.

The plasma was subjected for the assay of SOD [14], CAT [15], and GST [16], the protein content was identified by the method [17], malondialdehyde and GSH. All the experimental protocols have adhered to the guidelines of the University Animal Welfare Committee (Research Ethics Committee A-17-06-04).

\section{Statistical analysis}

A thorough measurable analysis was held to decide the contrasts between control levels of the enzymes under examination with respect to treatments given to animals. A one-way ANOVA test was utilized at $p=0.05$ because the data were obtained by repeated investigation. A paired $t$-test was additionally performed at $p<0.05$ to confirm if the results had changed significantly (followed by a conjugal comparison with explicit Tukey's analysis). A similar statistical analysis was performed to assess the difference in enzyme activity in non-stressed control rats that received treatments with extract before and after stress.

\section{RESULTS}

The $6 \mathrm{~h}$ of immobilization stress resulted in a significant decrease in the brain activities of SOD $(p<0.001)$, GST $(p<0.01)$, CAT $(p<0.001)$, and the levels of GSH $(\mathrm{p}<0.001)$ with significantly increased levels of thiobarbituric acid reactive substance (TBARS) $(\mathrm{p}<0.001)$ in comparison to non-stressed (control) rats (Table 1 and Fig. 1). A single dose of $P$. quadrifida extract alone $(100 \mathrm{mg} / \mathrm{kg}$ body weight $)$ has not caused a significant change in the previously mentioned parameters (results not shown) in unstressed control rats. Oral administration of $P$. quadrifida extract both before (pre-stress treatment) and after (post-stress treatment) immobilization stress treatment resulted in a significant modification of these parameters as compared to stresstreated rats and reverted these parameters toward their control values.

However, the post-stress oral treatment of extract $(100 \mathrm{mg} / \mathrm{kg}$ body weight) was more efficient in restricting stress-induced decline of SOD $(\mathrm{p}<0.05)$, GST $(\mathrm{p}<0.02)$, CAT $(\mathrm{p}<0.05)$, and GSH $(\mathrm{p}<0.05)$ and an enhanced level of TBARS $(\mathrm{p}<0.01)$ compared to stress alone or prestress extract treatments.

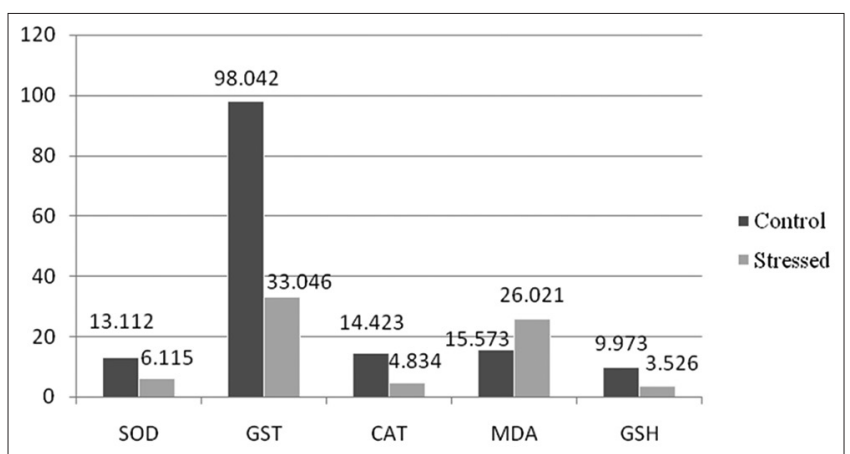

Fig. 1: Effect of immobilization stress on brain tissue activities of superoxide dismutase, glutathione-S-transferase, catalase, and glutathione content compared to control rats

Table 1: Immobilization stress effect on brain tissue activities of enzymes compared to control rats

\begin{tabular}{lllll}
\hline Groups & $\begin{array}{l}\text { SOD (U/mg } \\
\text { protein) }\end{array}$ & $\begin{array}{l}\text { GST (U/mg } \\
\text { protein) }\end{array}$ & $\begin{array}{l}\text { CAT (U/mg } \\
\text { protein) }\end{array}$ & $\begin{array}{l}\text { MDA (nmol/mg (nmol/mg } \\
\text { protein) }\end{array}$ \\
\hline Control (6) & $13.112 \pm 3.12$ & $98.042 \pm 4.12$ & $14.423 \pm 3.31$ & $15.573 \pm 1.23$ \\
Stressed (6) & $6.115 \pm 2.11^{\mathrm{d}}$ & $33.046 \pm 6.32^{\mathrm{c}}$ & $4.834 \pm 3.32^{\mathrm{d}}$ & $26.021 \pm 1.26^{\mathrm{d}}$ \\
Crude extract (6) & $14.123 \pm 3.05$ & $92.988 \pm 8.23$ & $13.241 \pm 1.09$ & $14.613 \pm 2.01$ \\
\hline
\end{tabular}

The number of experimental rats is indicated in the parenthesis. ${ }^{\mathrm{a}} \mathrm{p}<0.05,{ }^{\mathrm{b}} \mathrm{p}<0.02,{ }^{\mathrm{c}} \mathrm{p}<0.01,{ }^{\mathrm{d}} \mathrm{p}<0.001$, as compared with control rats. SOD: Superoxide dismutase,

GST: Glutathione-S-transferase, CAT: Catalase, MDA: Malondialdehyde, GSH: Glutathione 
No significant alterations in the parameters of controls were shown after the intragastric administration of flavonoid and alkaloid fractions. However, the treatment with the active constituents of $P$. quadrifida, both before and after the immobilization stress, caused a significant reversion of the stress-induced altered parameters toward their normal values but with a relative dominance by the latter (Tables 2 and 3).

In Fig. 2, the results show that the active constituents of this plant, both before and after the immobilization stress, altered biochemical parameters toward their normal values. However, the post-stress oral treatment of extract was found more effective in restricting stress.

\section{DISCUSSION}

The cells in the body are exposed to oxidants from various sources but are also equipped with an antioxidant system $[18,19]$. There are numerous explanations for the failure of the antioxidant defense system which could be either due to the excess production of free radicals or declined activities of scavenging enzymes or both of them that leads to lipid peroxidation and the oxidation of only few lipids can result in serious tissue damage and disease since lipid peroxidation is a self-propagating chain reaction $[20,21]$. Plant extracts can provide an essential aspect of the antioxidant system by attenuating free radicals [22]. A vital importance of the antioxidants present in P. quadrifida plant's extracts in stress modulation can show the use of this extract as a therapeutic supplemental nutritional agent in the disorders related with the free radical damage.

A known way for the production of chronic emotional and physical stress is restraint stress and is shown to bring about antioxidant changes in the brain of the rats [23]. In our study, $6 \mathrm{~h}$ of restraint stress resulted in a significant decrease in CAT, GST, SOD and activities, and

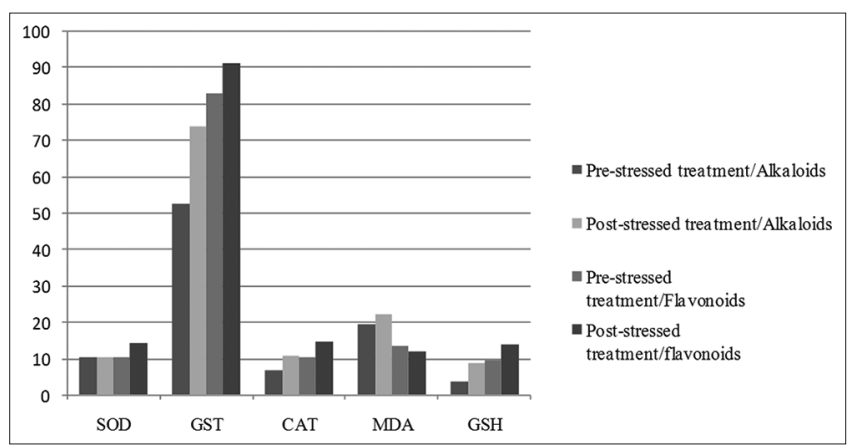

Fig. 2: Treatment with the active constituents of Portulaca quadrifida, both before and after the immobilization stress
GSH levels along with a significant rise in TBARS levels, which is a sign of lipid peroxidation. The observed changes in the above-mentioned parameters are due to the generation of ROS in the rat's brain. The depletion of GSH content in rat brain may also result in increased lipid peroxidation, which serves as one of the guarding factors against oxidative stress [24]. GSH decreased levels might also be because of the declined activities of GST, SOD, and CAT. The GST enzymatic machinery also has peroxidase activity, which can directly attack the peroxides generated through oxidative reduction recycling [19]. The reduced GST activity observed in our study might also have contributed to the increased lipid peroxidation and the treatment of rats both before and after stress with crude extract of $P$. quadrifida leaves and its active constituents resulted in a significant increase in the antioxidant enzymes activities and GSH level along with a decrease in LPO (Figs. 1 and 2). Post-stress treatments of extract and its active constituents were found more effective in combating stress-induced prooxidant changes compared with pre-stress extract treatments (Tables 2 and 3).

The rats that received extract of $P$. quadrifida before being exposed to stress showed a significant resistance toward the derangement of their oxidative metabolism triggered by restraint stress, though the postextract treatment (therapeutic) was more effective in restoring the altered oxidative metabolism toward their control values compared with pre-extract treatment (prophylactic). P. quadrifida has been reported in scientific literature as an effective antioxidant for the protection against diseases as a result of oxidative stress [25-27]. The extract was reported to contain many polyphenolic compounds, mainly flavonoids such as quercetin and rutin and some of the other chemical constituents reported in leaves are riboflavin, $\alpha$-tocopherol, ascorbic acid, and GSH. The antioxidant property of $P$. quadrifida extract observed in our study might be due to the presence of polyphenolic compounds, GSH, and ascorbic acid. Our results also indicate that P. quadrifida extract could be used as a dietary supplement to fight various neurodegenerative diseases.

\section{CONCLUSION}

The extract of $P$. quadrifida before being exposed to stress showed a significant resistance toward the oxidative metabolism triggered by restraint stress, though the post-extract treatment (curative) was observed to be more effective in restoring the altered oxidative metabolism compared with pre-extract treatment (prophylactic). The antioxidant property of this plant extract recorded in our study could be due to the presence of the $\beta$-carotene, Vitamin $C$, and polyphenolic compounds. Our results also indicate that this plant extract could be used as a dietary supplement to combat and fight various neurodegenerative diseases and in terms of effects of alkaloids, tannins

Table 2: Treatment with the active constituents (alkaloid fractions) of $P$. quadrifida, both before and after the immobilization stress

\begin{tabular}{|c|c|c|c|c|c|}
\hline Groups & $\begin{array}{l}\text { SOD }(\mathrm{U} / \mathrm{mg} \\
\text { protein) }\end{array}$ & $\begin{array}{l}\text { GST (U/mg } \\
\text { protein) }\end{array}$ & $\begin{array}{l}\text { CAT }(\mathrm{U} / \mathrm{mg} \\
\text { protein) }\end{array}$ & $\begin{array}{l}\text { MDA (nmol/mg } \\
\text { protein) }\end{array}$ & $\begin{array}{l}\text { GSH (nmol/mg } \\
\text { protein) }\end{array}$ \\
\hline Alkaloid fraction (6) & $12.235 \pm 1.15$ & $87.716 \pm 9.32$ & $10.741 \pm 1.24$ & $14.601 \pm 1.62$ & $9.092 \pm 1.37$ \\
\hline Pre-stressed alkaloid treatment (6) & $10.321 \pm 1.24^{c}$ & $52.739 \pm 6.62^{\mathrm{b}}$ & $6.737 \pm 1.01^{\mathrm{a}}$ & $19.212 \pm 1.83^{\mathrm{a}}$ & $3.376 \pm 1.03^{\mathrm{a}}$ \\
\hline Post-stressed alkaloid treatment (6) & $10.198 \pm 1.68^{\mathrm{a}}$ & $73.788 \pm 13.83^{\mathrm{b}}$ & $10.722 \pm 3.16^{\mathrm{b}}$ & $22.182 \pm 2.81^{\mathrm{c}}$ & $8.612 \pm 1.56^{\mathrm{b}}$ \\
\hline
\end{tabular}

The number of experimental rats is indicated in the parenthesis. ${ }^{\mathrm{a}} \mathrm{p}<0.05,{ }^{\mathrm{b}} \mathrm{p}<0.02,{ }^{\mathrm{c}} \mathrm{p}<0.01,{ }^{\mathrm{d}} \mathrm{p}<0.001$, as compared with stress alone. SOD: Superoxide dismutase,

GST: Glutathione-S-transferase, CAT: Catalase, MDA: Malondialdehyde, GSH: Glutathione, P. quadrifida: Portulaca quadrifida

Table 3: Treatment with the active constituents (flavonoid fractions) of $P$. quadrifida, both before and after the immobilization stress

\begin{tabular}{llllll}
\hline Groups & $\begin{array}{l}\text { SOD (U/mg } \\
\text { protein) }\end{array}$ & $\begin{array}{l}\text { GST (U/mg } \\
\text { protein) }\end{array}$ & $\begin{array}{l}\text { CAT (U/mg } \\
\text { protein) }\end{array}$ & $\begin{array}{l}\text { MDA (nmol/mg } \\
\text { protein) }\end{array}$ & $\begin{array}{l}\text { GSH (nmol/mg } \\
\text { protein) }\end{array}$ \\
\hline Flavonoid (6) & $15.321 \pm 2.10$ & $107.365 \pm 15.19$ & $13.465 \pm 3.018$ & $16.731 \pm 3.01$ & $10.618 \pm 1.92$ \\
Pre-stressed flavonoid treatment (6) & $10.125 \pm 2.19^{\mathrm{a}}$ & $83.121 \pm 10.33^{\mathrm{a}}$ & $10.367 \pm 2.28^{\mathrm{b}}$ & $13.623 \pm 1.97^{\mathrm{a}}$ & $9.512 \pm 1.23^{\mathrm{a}}$ \\
Post-stressed flavonoid treatment (6) & $14.227 \pm 1.13^{\mathrm{a}}$ & $91.128 \pm 9.13^{\mathrm{b}}$ & $14.737 \pm 2.97^{\mathrm{c}}$ & $11.715 \pm 2.86^{\mathrm{c}}$ & $13.712 \pm 1.43^{\mathrm{d}}$ \\
\hline
\end{tabular}

The number of experimental rats is indicated in the parenthesis. ${ }^{\mathrm{a}} \mathrm{p}<0.05,{ }^{\mathrm{b}} \mathrm{p}<0.02,{ }^{\mathrm{c}} \mathrm{p}<0.01,{ }^{\mathrm{d}} \mathrm{p}<0.001$, as compared with stress alone. SOD: Superoxide dismutase,

GST: Glutathione-S-transferase, CAT: Catalase, MDA: Malondialdehyde, GSH: Glutathione, P. quadrifida: Portulaca quadrifida 
and others, our current study results were in accordance with a study done in 2016 which provided a general evidence that the extract of this plant contains medicinally important compounds and our study discussed the detailed specific neurological effect which was proven in the current study [28].

\section{AUTHORS' CONTRIBUTIONS}

Moayad Shahwan designed the experiments, drafted, edited the manuscript, and interpreted the results, and Sabrina Ait Gacem did the experiments and statistical analysis.

\section{CONFLICTS OF INTEREST}

The authors declare that they have no conflicts of interest.

\section{FINANCIAL SUPPORT AND SPONSORSHIP}

Nil.

\section{REFERENCES}

1. Deepika KS, Rajagopal SV. Evaluation of in vitro anticancer potential of ethanolic extract and its different fractions of Caesalpinia bonduc (L) roxb Seeds. Int J Pharm Pharm Sci 2014;20 Suppl 1:311-4.

2. Halliwell B. Antioxidants and human diseases: A general introduction. Nutr Rev 1997;55:44-52.

3. Pietta PG. Flavonoids as antioxidants. J Nat Prod 2000;63:1035-42.

4. Ames BN, Gold LS, Willett WC. The causes and prevention of cancer. Proc Natl Acad Sci U S A 1995;92:5258-65.

5. Ejiofor UE, Ebhohon SO, Nwuke PC, Atasie OC, Oriaku CE. Ameliorative effect of methanol extract of Telfairia occidentalis hook and Amaranthus hybridus Linn. against cadmium induced oxidative stress in rats. J Appl Pharm Sci 2017;9:109-15.

6. Sharma R, Chandan G, Chahal A. Antioxidant and anticancer activity of methanolic extract from stephania elegans. Int J Pharm Pharm Sci 2017;85 Suppl 1:245-9.

7. Anamarija I, Sonja MM. Polyphenolic composition and antioxidant activities of grape seed extract. Int J Food Properties 2008;11:713-26.

8. Fauconneau B, Waffo-Teguo P, Huguet F. Comparative study of radical scavenger and antioxidant properties of phenolic compounds from Vitis vinifera cell cultures using in vitro tests. Life Sci 1997;61:2103-10.

9. Ekaiko M, Arinze A, John W, Ajah O. Antimicrobial effect of the leaf extract of Psidium guajava L. and Carica papaya L. Int J Life Sci Res 2015;3:55-60

10. Kirtikar KR, Basu BD. Indian Medicinal Plants. $2^{\text {nd }}$ ed. Mumbai: Prakashan Publications; 2001

11. Hoffman BR, Delas A, Blanco K. Screening of antibacterial and antifungal activities of ten medicinal plants from Ghana. Pharm Biol
2004;42:13-7

12. Mulla SK, Swamy P. Preliminary pharmacognostical and phytochemical evaluation of Portulaca quadrifida Linn. Int J Pharmtech Res 2010;2:1699-702.

13. Singh LK, Pang X, Alexacos N, Letourneau R, Theoharides TC. Acute immobilization stress triggers skin mast cell degranulation via corticotrophin releasing hormone neurotension and substance link to neurogenic skin disorders. Brain Behav Immunity 1999;13:225-39.

14. Marklund S, Marklund G. Involvement of the superoxide anion radical in the autoxidation of pyrogallol and a convenient assay for superoxide dismutase. Eur J Biochem 1974;47:469-74.

15. Beers RF Jr., Sizer IW. A spectrophotometric method for measuring the breakdown of hydrogen peroxide by catalase. J Biol Chem 1952; 195:133-40.

16. Habig WH, Pabst MJ, Jakoby WB. Glutathione S-transferases. The first enzymatic step in mercapturic acid formation. J Biol Chem 1974;249:7130-9.

17. Lowry OH, Rosebrough NJ, Farr AL, Randall RJ. Protein measurement with the folin phenol reagent. J Biol Chem 1951;193:265-75.

18. Tabrez S, Ahmad M. Effect of wastewater intake on antioxidant and marker enzymes of tissue damage in rat tissues: Implications for the use of biochemical markers. Food Chem Toxicol 2009;47:2465-78.

19. Tabrez S, Ahmad M. Cytochrome P450 system as a toxicity biomarker of industrial wastewater in rat tissues. Food Chem Toxicol 2010;48:998-1001.

20. Das M, Khanna SK. Clinicoepidemiological, toxicological, and safety evaluation studies on argemone oil. Crit Rev Toxicol 1997;27:273-97.

21. Levine WG. Glutathione, lipid peroxidation and regulation of cytochrome P-450 activity. Life Sci 1982;31:779-84.

22. Floyd RA, Carney JM. Free radical damage to protein and DNA: Mechanisms involved and relevant observations on brain undergoing oxidative stress. Ann Neurol 1992;32 Suppl 22:7.

23. Al-Qirim TM, Shahwan M, Zaidi KR, Uddin Q, Banu N. Effect of khat, its constituents and restraint stress on free radical metabolism of rats. J Ethnopharmacol 2002;83:245-50.

24. Payá M, Halliwell B, Hoult JR. Interactions of a series of coumarins with reactive oxygen species. Scavenging of superoxide, hypochlorous acid and hydroxyl radicals. Biochem Pharmacol 1992;44:205-14.

25. Gallo M, Conte E, Naviglio D. Analysis and comparison of the antioxidant component of Portulaca oleracea leaves obtained by different solid-liquid extraction techniques. Antioxidants (Basel) 2017;6:64

26. Mulla SK, Swamy P. Antioxidant activity of ethanolic and polyphenolic extracts of Portulaca quadrifida. Int J Biol Pharm Res 2012;3:392-9.

27. Uddin MK, JuraimiAS, Ali ME, Ismail MR. Evaluation of antioxidant properties and mineral composition of purslane (Portulaca oleracea L.) at different growth stages. Int J Mol Sci 2012;13:10257-67.

28. Verma SC, Kalyan H, Manish D, Maddi R, Biresh KS. Phytochemical and high-performance liquid chromatography analysis of extract of portulaca quadrifida linn. Asian J Pharm Clin Res 2016;9:164. 